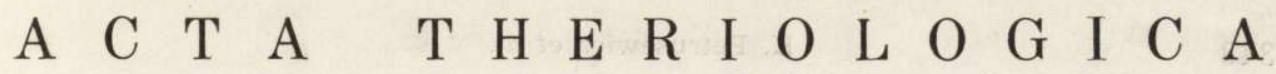 \\ VOL. XVII, 27: $347-353$. \\ BIAŁOWIEŻA \\ October, 1972
}

\author{
Kazimierz PETR U SE W I C Z, Georgij M A R K O V, \\ Joanna G L I W I C Z \& Lubomir CHR IS T O V
}

\section{A Population of Clethrionomys glareolus pirinus on the Vitosha Mountain, Bulgaria. IV. Production}

[With 5 Tables \& 2 Figs.]

\begin{abstract}
Animal production per 6 ha was $4.2-5.3 \mathrm{~kg}$ live weight, $48 \%-54 \%$ of which was produced by the spring cohort. From $13 \%-15 \%$ of total production was formed by newborn young $\left(P_{b}\right)$ and $52 \%-55 \%$ by the body growth of suckligs (to 21 days). Production during the reproduction season accounted for about $90 \%$, and during winter about $10 \%$ of total production $\left(P_{T}\right)$. Average biomass per 6 ha was $1.2 \mathrm{~kg}-1.7 \mathrm{~kg}$. Turnover was 3.1 and 3.5 .
\end{abstract}

\section{INTRODUCTION}

The analysis present here is an attempt to define production, elimination, and turnover in a free-living population of Clethrionomys glareolus, considering production by different cohorts (due to reproduction and to body growth) along with production in winter.

Data were obtained by cooperation of the Institute of Ecology Polish Academy of Sciences and the Institute of Zoology, Bulgarian Academy of Sciences, under the International Biological Programme. Populations were censused four times during June and September 1967 and 1968 on a 6 ha plot in the spruce forest of Vitosha Mountain by the Standard Minimum method (see Markov, et al., 1972b). Individual growth curves (Christov \& Markov, 1972), natality estimates, population fluctuation and cohort survival indices have been reported ( $\mathrm{M} \mathrm{a} \mathrm{r} \mathrm{k} \mathrm{ov}$ et al., 1972a, b). These four cohorts are defined by $\mathrm{Markov}$ et al., $1972 \mathrm{a}$.

\section{PRODUCTION CALCULATIONS}

Production $(P)$ was calculated by the Nees \& D ugdale method (Petrusewicz \& Madfadyen, 1970) from growth data of 
Christov \& Markov (1972) and cohort viability data of Mar$\mathrm{k}$ ov et al. (1972b). By plotting number of individuals against their weight, a curve, the area under which indicates cohort production (Figs. 1 and 2) is obtained. Total production of all cohorts constitutes population production. Reproductive production $\left(P_{r}\right)$, production due to body growth $\left(P_{g}\right)$, and the various cohort productions are easily distinguished by this method.

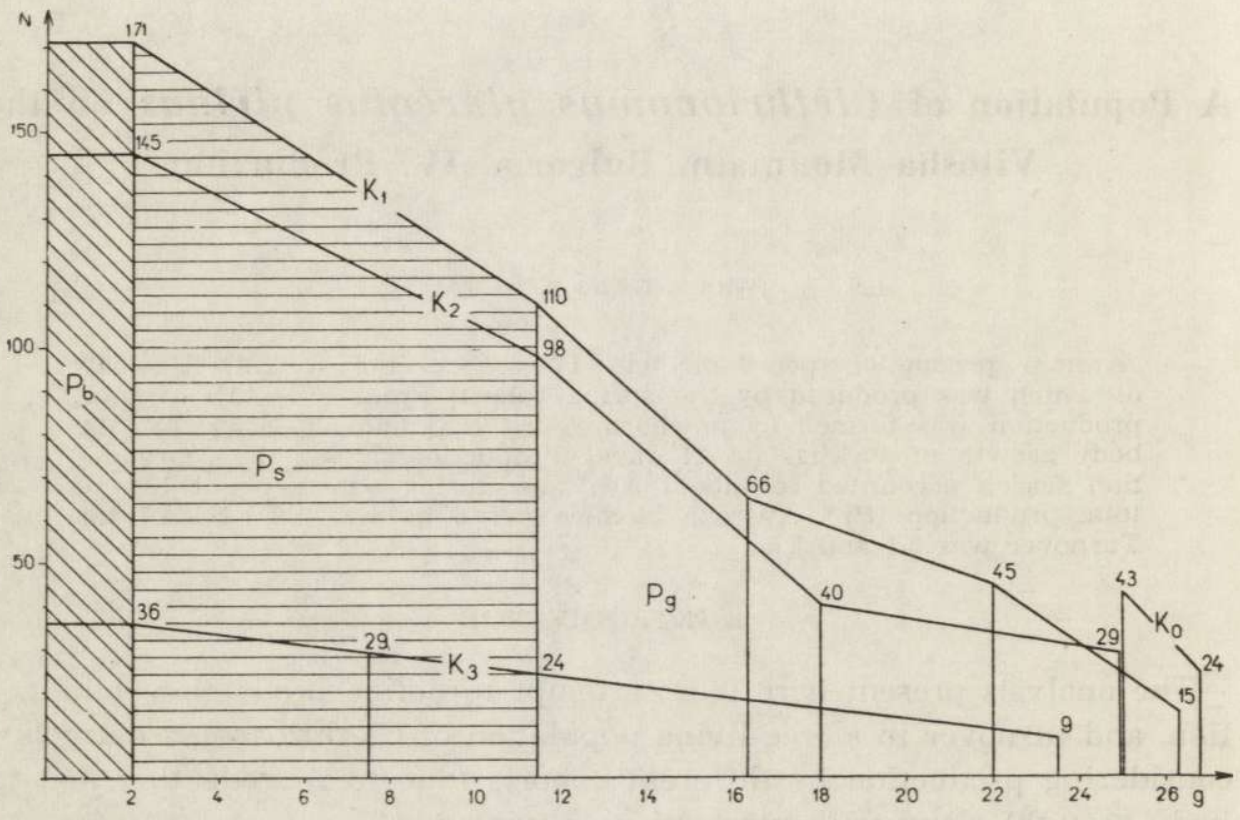

Fig. 1. Calculation of population production in 1967. Numbers of curves indicate the number of individuals which survived to the age expressed by weight on axis of abscissae. Production of each cohort is defined by the area under the given curve.

$P_{p}$ - weight of animals born, $P_{s}$ - production during period of feeding on mother's milk (up to 21 days): $P_{g}$ production due to body growth (production of independent components of the population). Values of numbers for 6 ha.

\section{DISCUSSION OF POPULATION PRODUCTION}

\subsection{Cohort Production}

Participation in annual production $(P)$ by the various cohorts was analyzed, taking April 1, the beginning of the breeding season, as the beginning of the year. Thus a year in the C. glareolus population lasts from April 1 to March 31 the following year. Old adults form the starting point, spring and summer constitute a period of intensive reproduc- 
tion, autumn and winter a period of reproductive quiesence, and the current year's generations survive to spring, starting the new breeding season.

Differential cohort production analysis (Table 1) shows that spring $\left(K_{1}\right)$ and summer $\left(K_{2}\right)$ cohorts clearly exhibit maximum production. Together they contribute $88-97 \%$ of total production. Old adults exhibit minimum production due to decreased body growth, only $1-2 \%$. The autumn cohort (born in September) produces from $1 \%$ (1968) to $10 \%$ (1967).

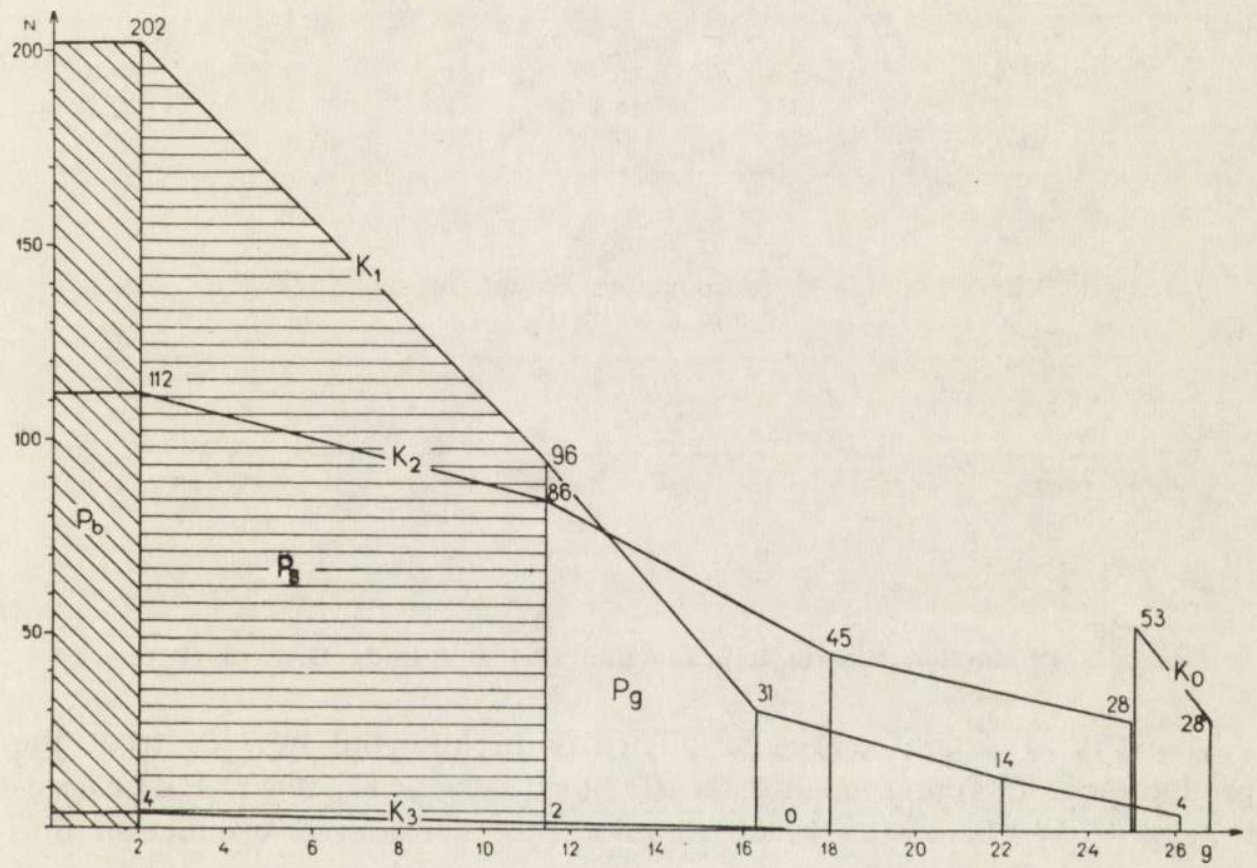

Fig. 2. Calculation of population production in 1968. Symbols as for Fig. 1.

It is difficult to exactly compare the portion of production contributed by cohorts from Vitosha Mountain with similarly analized results from a Polish island population of C. glareolus (P e trusewicz et al., 1968, $1969,1971)$ because cohorts in the two locations do not exactly correspond. $K_{1}$ and $K_{4}$ of Gliwicz et al. (1968) correspond approximately to $K_{1}$ and $K_{3}$ in the present study. In both populations spring and summer generations contribute greatly to production, but under the 
conditions prevailing on Vitosha Mountain the earlier generation contributes more; $K_{1}$ produces $48 \%-54 \%$ of the total, whereas in Poland summer cohorts $\left(K_{2}\right.$ and $\left.K_{3}\right)$ collectively produce more than the $K_{1}$. Average $K_{1}$ production for 3 years is $34 \%$ compared with $53 \%$ produced by $K_{2}$ and $K_{3}$ (Petrusewicz et al., 1971).

Table 1

Participation of cohorts in production, yearly production per 6 ha in grammes of live weight.

\begin{tabular}{|c|c|c|c|c|}
\hline \multirow[b]{2}{*}{ Cohort } & \multicolumn{2}{|c|}{1967} & \multicolumn{2}{|c|}{1968} \\
\hline & g & ${ }_{0}^{0}$ & g & $\stackrel{0}{\circ}$ \\
\hline$K_{0}$ & 68 & 1.3 & 82 & 1.9 \\
\hline$K_{1}$ & 2534 & $\triangle 8.1$ & 2283 & 53.7 \\
\hline$K_{2}$ & $21 \leq 9$ & $\measuredangle 0.2$ & 1842 & 43.4 \\
\hline$K_{3}$ & 554 & 10.4 & 42 & 1.0 \\
\hline$P_{\mathrm{yr}}$ & 5285 & 100 & 4249 & 100 \\
\hline
\end{tabular}

Table 2

Production due to reproduction growth of sucklings $\left(P_{s}\right)$ and growth $\left(P_{\mathrm{g}}\right)$.

\begin{tabular}{|c|c|c|c|c|c|c|}
\hline \multirow{2}{*}{ Year } & \multicolumn{2}{|c|}{${ }^{P_{T}}$} & \multirow[t]{2}{*}{$F_{b}$} & \multirow{2}{*}{$+\begin{array}{r}P_{s} \\
q \\
\end{array}$} & \multirow{2}{*}{$=P_{r}$} & \multirow{2}{*}{$\begin{array}{l}P_{g} \\
\% \\
\end{array}$} \\
\hline & g & $\%$ & & & & \\
\hline 1967 & 5285 & 100 & 13 & 52 & 65 & 35 \\
\hline 1968 & 4249 & 100 & 15 & 55 & 70 & 30 \\
\hline
\end{tabular}

\subsection{Production Due to Reproduction $\left(\mathrm{P}_{\mathrm{r}}\right)$ and Body Growth $\left(\mathrm{P}_{\mathrm{g}}\right)$}

There is a certain degree of difficulty in knowing how to treat the production of young mammals (Petrusewicz, 1967; Petrusewicz \& Walkowa, 1968). Should it be considered production due to breeding $\left(P_{r}\right)$ since it occurs wholly or partially at the expense of maternal nourishment, or as body growth production $\left(P_{g}\right)$ ? By differentating between biomass of newborn individuals $\left(P_{b}\right)$, biomass increase of sucklings $\left(P_{s}\right)$, it was concluded that production occurs partly at the expense of the mother. Thus, $P_{r}=P_{b}+P_{s}$.

Table 2 shows that $52 \%-55 \%$ of production is due to suckling growth $\left(P_{s}\right)$. Reproductive production is $65 \%-70 \%$ of all production. These values do not differ greatly from those obtained for the island population in Poland (Petrusewicz et al., 1968), the numbers of which were accurately established. There, $P_{b}$ biomass was $13 \%$ compared with $13 \%$ - $-15 \%$ for the Vitosha population, and $P_{r}$ was $58 \%$, compared with 
$65 \%-70 \%$ for Vitosha. It is difficult to judge whether the difference in production of sucklings ( $43 \%$ in Poland) is significantly less than for Vitosha since 4 population censuses were made yearly in Poland and the population was isolated, whereas on Vitosha Mountain the census was made only twice yearly.

Comparison of productivity during the breeding season (AprilSeptember) and winter (October-March) indicated that $88 \%-93 \%$ of net annual production occurs during the growing season (Table 3 ). This agrees with the Polish population data (Petrusewicz et al., 1968), where only $10 \%$ of the total production occurs in winter.

Table 3

Production during winter and summer seasons.

\begin{tabular}{crrrr}
\hline \multirow{2}{*}{ Period } & \multicolumn{2}{c}{ Summer } & \multicolumn{2}{c}{ Winter } \\
& 1.IV $-22 . \mathrm{IX}$ & \multicolumn{2}{c}{ 22.IX $-1 . \mathrm{IV}$} \\
$\mathrm{g}$ & $\%$ & $\mathrm{~g}$ & $\%$ \\
\hline 1967 & 4612 & 88 & $€ / 3$ & 1 \\
1968 & 3940 & 93 & 309 & 7 \\
\hline
\end{tabular}

Table 4

Production $(P)$, elimination $(E)$ and increase in standing crop $\left(B=B_{T}-B_{o}\right)$ during reproduction and winter seasons.

\begin{tabular}{|c|c|c|c|}
\hline & $\begin{array}{l}\text { Reproduction period }(\mathrm{IV}-\mathrm{X}) \\
\quad P=E+\left(B_{T}-B_{o}\right)\end{array}$ & $P$ & $\begin{array}{l}\text { Winter }(\mathrm{X}-\mathrm{III}) \\
=E+\left(B_{T}-B_{o}\right)\end{array}$ \\
\hline 1967 & $\begin{array}{c}4612=3627+(2065-1080) \\
100\end{array}$ & & $\begin{array}{l}637=1372+(1330-2065) \\
100 \quad 215 \quad-115\end{array}$ \\
\hline 1868 & $\begin{array}{c}3940=4034 \\
100 \\
103\end{array}$ & & $\begin{array}{l}309=743+(802-1236) \\
100 \quad 240 \quad-140\end{array}$ \\
\hline
\end{tabular}

3.3 Production and Elimination in Summer and Winter

In a balanced population almost all net production (averaged over several years) is eliminated so that biomass accumulation, $\Delta B=B_{T}-B_{o}$ in the equation $P=E+\Delta B$ is very small. It is, however, interesting to trace separately the fate of the biomass produced during the reproduction and the winter seasons. During the reproduction season $3 \%-21 \%$ of production is due to biomass growth, but during the winter most or even the all accumulated biomass is eliminated from the population (Table 4).

During the winter, production in the form of body growth in only $7 \%$ to $12 \%$ of the whole years' production, and is less than mortality. Consequently $\triangle B=B_{T}-B_{o}$ is a negative value; the standing crop decreases from autumn to spring by $434-735 \mathrm{~g}$ of biomass, i.e., by approximately $35 \%$ of the autumn standing crop (Table 4 ). 


\section{AVERAGE BIOMASS AND TURNOVER}

The average standing crop for the year (number of individuals, live weight, or number of biomass-days, during a year) describes a population well. Biomass-days (B.T.) is perhaps the best estimate since this expresses the mass which consumes, assimilates, digests, and respires. The calculated values in Table 5 vary for the two study years and are clearly lower than in the population of $C$. glareolus in Poland. It is interesting that with markedly different standing crops that turnover is similar in both years and does not differ greatly from the turnover in the population in Poland (3.1 and 3.5 compared with 3.7 ; P e trus ewi c z et al., 1969).

\section{Table 5}

Average biomass $(\bar{B})$, value of biomass-days $(\bar{B} \cdot T)$ (live wt per year, per $6 \mathrm{ha}$ in $10^{3} \mathrm{~g}$ ) and turnover $\Theta$ (per year).

\begin{tabular}{lcccc}
\hline Year & $\bar{B}, T$ & $\bar{B}=\frac{\bar{B} T}{365}$ & $P$ & $\Theta=P \bar{B}$ \\
\hline 1967 & 624.1 & 1.71 & 5.29 & 3.1 \\
1968 & 442.3 & 1.21 & 4.25 & 3.5 \\
\hline
\end{tabular}

It is remarkable that while production of young to 21 days old is $65 \%-70 \%$ of total production, the participation of sucklings in average biomass or in number of biomass-days is negligible since in the latter $\bar{B} \cdot T$ for 1967 is $(35.1: 624.1) \quad 100=5.6 \%$, and for $1968 \quad(28.6: 442.3)$ $100=6.4 \%$. Despite the enormous number of individuals they weigh little and, more importantly, their lifetime as sucklings is very short, lasting at most 21 days. They therefore do not greatly affect the mass and number of individuals living over the course of the year.

Acknowledgements: The authors are indebted to Dr. G. L. Dry den for revising the English text.

\section{REFERENCES}

1. Christov L. \& Markov G., 1972: A population of Clethrionomys glareolus pirinus on the Vitosha Mountain, Bulgaria. III. Individual growth curve. Acta theriol., 17, 26: 343-346.

2. Gliwicz J., Andrzejewski R., Bujalska G. \& Petrusewicz K., 1968: Productivity investigation of an island population of Clethrionomys glareolus ( $\mathrm{Schreber}, 1780$ ). I. Dynamics of cohort. Acta theriol., 13: 401-413.

3. Markov G., Bujalska G. \& Christov L., 1972a: A population of Clethrionomys glareolus pirinus on the Vitosha Mountain, Bulgaria. II. Natality. Acta theriol., 17, 25: 337-342. 
4. Markov G., Christov L. \& Gliwicz J., 1972b: A population of Clethrionomys glareolus pirinus on the Vitosha Mountain, Bulgaria. I. Variations in numbers and age structure. Acta theriol., 17, 24: 327-335.

5. Petrusewicz K., 1967: Concepts in studies on the secondary productivity of terrestrial ecosystems. [In: "Secondary productivity of terestrial ecosystems ", ed. K. Petrusewicz]: 17-49. Państw. Wyd. Nauk. Warszawa-Kraków.

6. Petrusewicz K., Andrzejewski R., Bujalska G. \& Gliwicz J., 1968: Productivity investigation of an island population of Clethrionomys glareolus ( $\mathrm{S} \mathrm{chreber}$, 1780). IV. Production. Acta theriol., 13: 435-445.

7. Petrusewicz K., Andrzejewski R., Bujalska G. \& Gliwicz J., 1969/1970: The role of spring, summer and autumn generations in productivity of free living population of Clethrionomys glareolus ( $\mathrm{S} \mathrm{chreber}, 1780$ ). [In: "Energy flow through small mammal populations", eds. K. Petrusewicz \& L. Ryszkowski]: 235-247. Państw. Wyd. Nauk. Warszawa.

8. Petrusewicz K., Bujalska G., Andrzejewski R. \& Gliwicz J., 1971: Productivity processes in an island population of Clethrionomys glareolus. Ann. zool. Fennici 8: 127-132.

9. Petrusewicz K. \& Macfadyen A., 1970: Productivity of terrestrial animals. Principles and methods. (I.B.P. Handbook No. 13). Blackwell Sci. Publ.: 1-186. Oxford-Edinburgh.

10. Petrusewicz K. \& Walkowa W., 1968: Contribution of production due to reproduction to the total production of the population and individuum. Bull. Acad. Pol. Sci., Cl. II, 16: 439-442.

Accepted, July 27, 1972.

Kazimierz Petrusewicz, Joanna Gliwicz Institute of Ecology,

Polish Academy of Sciences,

Dziekanów n/Warszawa, Poland.
Georgij Markov, Lubomir Christov Institute of Zoology, Bulgarian Academy of Sciences, Sofia, Ruski 1, Bulgaria.

\section{Kazimierz PETRUSEWICZ, Georgij MARKOV, Joanna GLIWICZ i Lubomir CHRISTOV}

\section{POPULACJA CLETHRIONOMYS GLAREOLUS PIRINUS W LESIE SWIERKOWYM MASYWU WITOSZA W BUÆGARII. IV. PRODUKCJA}

\section{Streszczenie}

W wolno żyjącej populacji Clethrionomys glareolus na masywie Witosza koło Sofii produkcja obliczona metodą graficzną Neesa i Dugdale'a (Petrusewicz i M a cfadyen, 1970) wyniosła w różnych latach $4,2-5,3 \mathrm{~kg}$ biomasy/rok $/ 6$ ha (Tabela 1). Wyraźnie najwyższa była produkcja generacji wiosennej i wyniosła $48-54 \%$ całej produkcji, natomiast $52-55 \%$ całej produkcji stanowiła produkcja wzrostu młodych żywiących się, przynajmniej częściowo, kosztem matki (Tabela 2). Zaledwie $10 \%$ przypada na produkcję zimą (Tabela 3 ). Średnia biomasa w ciągu dwóch lat badanych wynosiła $1,21-1,71 \mathrm{~kg}$ biomasy/6 ha. Turnover biomasy obliczono na 3.1 i 3.5 . 